\title{
Oedipal Desire in Bernard Rose's Frankenstein
}

\author{
Mridula Sharma
}

Department of English, Maharaja Agrasen College, University of Delhi, New Delhi, India

\begin{abstract}
Mary Shelley's attempt to create a Female Gothic in the textual space of Frankenstein; or, The Modern Prometheus (1818) has enabled the inauguration of critical discourse in a novel that refutes generic classifications. Bernard Rose's film titled, Frankenstein (2015), has appropriated Mary Shelley's nineteenth-century novel for contemporary viewers. The insertion of the monster's Oedipal desire for Elizabeth in the cinematic adaptation supplements the investigation of orthodox romantic ideals by visualizing potentialities in the story. This paper endeavors to critique the illustration of the Oedipal Complex in Rose's film to comprehend the significance of its incorporation in the plot.
\end{abstract}

Keywords-Mary Shelley, Frankenstein, Bernard Rose, Monster, Oedipal Complex.

\section{INTRODUCTION}

Paul O'Flinn claims that "there is no such thing as Frankenstein, there are only Frankensteins, as the text is ceaselessly rewritten, reproduced, refilmed and redefined" (p.22). The placement of Mary Shelley's 1818 novel continues to shift from one medium to another for the production of yet another interpretation of the argument presented in the textual space. Bernard Rose's Frankenstein (2015) offers a plurality of meanings that reinforces one's belief in the reconstitution of interpretation irrespective of authorial intention.

Existing scholarship around Mary Shelley's Frankenstein (1818) fails to confine the novel within a rigid bracket of genre since its interpretative scope transgresses conventional generic divides. Though the reconfiguration of the monster's story in Rose's film deviates from novelistic discourse, it proposes novel arguments within the domain of psychoanalytic criticism. In this paper, I will focus on the examination of the monster's Oedipal desire for his maternal equivalent.

The narrative technique utilized by Rose eliminates the setting created by frame narrators to instead offer the outlook of the monster. Frankenstein's monster shifts to the forefront in the film and finally becomes an agent in dictating the story of the cinematic adaptation to the implied viewers. It is interesting to note that the film's divergence from Kantian aesthetics is accompanied by its construction of a typical Female Gothic.

The monster becomes a Romantic spokesperson like Coleridge's Ancient Mariner: his narrative is meant for informing his viewers, not entertaining them. Like the Mariner, the monster is uncovering the sequence of events in hindsight to verbalize his traumatic experience in an attempt to seek closure. His expectation from this endeavor is the communication of his private distress created as a consequence of being considered the 'Other.' The process of his 'Otherisation' accelerates when his romantic feelings for Elizabeth are revealed. In this way, the film interrogates contemporary understanding of complex issues.

In this article, I will investigate the explicit emphasis on the monster's Oedipal desire for his maternal equivalent and Rose's effort to satisfy the monster's quest for romance with the monster's eventual union with Elizabeth in his final moments before death. I attempt to identify the ramifications of Elizabeth's identification of the monster with a Biblical name like 'Adam' on the subsequent portrayal of their incestuous union. The nature of their relationship will be examined to identify how Elizabeth can be located within the nexus of his maternal guardian.

\section{THE MONSTER'S OEDIPAL DESIRE FOR ELIZABETH}

The film remodels Mary Shelley's narrative for cotemporary viewers: the prohibition of the monster's admission in the societal realm becomes inevitable after Rose's Frankenstein completes his unsuccessful biopsy that leads to the metamorphosis of the monster's skin. An unexpected eruption of scarlet-colored boils leads to the attachment of the label of monstrosity to the monster. He is unsuccessful in retaining the initial acceptance by his creators, especially by Frankenstein. Frankenstein aborts any further attempts to remodel his creature's physical appearance for social sanction. 
Elizabeth's acceptance of the monster as a 'conscious living entity' as opposed to Frankenstein's initial dismissal and subsequent rejection positions her as a maternal nurturer for the monster from the beginning of the film. Mary Shelley's monster stretches out his hands toward Frankenstein as a probable consequence of his intrinsic need to seek refuge in the arms of his creator. Rose's monster, in contrast, directs the performance of the same action toward Elizabeth. The sequence of events and the psychology of the involved characters within the narrative framework of the novelistic tradition do not permit the authorial voice to allow Frankenstein's reciprocation. Since Rose's monster reaches out to Elizabeth's character, acknowledgement of his affection is plausible because of both the identification of women as caregivers and Elizabeth's depiction as a nurturing character.

The impression of physical proximity at the onset of their relationship reveals the possibility of gradual development of the Oedipal complex. After the monster spits the semiliquid food that Elizabeth attempts to feed him while instructing him during the process of intaking food, he snatches the bottle of milk from her hand and forces her to feed him milk while she is leaning over his frame. This allows the creation of an Oedipal interlude that gains prominence with progress in the narrative. That their position corresponds to an image of a mother breastfeeding her child adds support to the supposition that the incorporation of romantic elements within their relationship purports the adoption of Freudian analysis during the process of critical examination.

Investigation of the Oedipal complex within the cinematic framework implies that the monster shares antipathy toward Frankenstein while simultaneous affection for Elizabeth. Before the conduction of biopsy, Frankenstein and Dr Marcus treat the monster as a plaything and engage with him to assess his cognitive development in his initial stage. Their interest in him as an experiment is affirmed by Frankenstein's constant reference to him as a 'good boy': though the phrase appears to play a crucial role in humanizing the monster by comparing him to a human boy having seemingly 'good' characteristic features, a deeper inquiry in its origin reveals that the popular employment of the phrase serves the need to enable the comparison with a domesticated animal. Frankenstein's decision to dispose the monster's apparently hideous body after witnessing the aftermath of biopsy is perhaps added to complicate the romantic conflict and intensify the layers of discord between him and his monster.

The escape from Frankenstein's laboratory eventually leads the monster to seek refuge near a small pond where he dreams of Elizabeth lying atop him, with her head on ISSN: 2456-7620 his chest, in a fashion similar to the one in which they were earlier positioned during the episode that symbolized breastfeeding. This dream translates into reality when Elizabeth's accidental murder by Frankenstein makes her fall on the heavily bruised body of the monster toward the end of the film.

The film ends with the monster entering his funeral pile holding Elizabeth in his hands. The Deleuzian double is repeated differently throughout the plot of the film: constant recurrence of the romantic partnership of Elizabeth with the monster underlines the emphasis on their incestuous association and therefore eliminates the Oedipal complex generated within the textual domain by the removal of Frankenstein's mother as well as the eradication of Elizabeth's placement as his cousin.

The adoption of Elizabeth Lavenza by the Frankensteins in Mary Shelley's narrative in combination with Frankenstein's development of desire toward her is read by David Collings as Frankenstein's need to substitute his dead mother with a maternal equivalent. The textual Elizabeth assumes the responsibilities of Caroline Beaufort in both managing the entire household and acting as a nurturer for the family.

The Oedipal drama is completed by the insertion of the following features: Caroline's replacement by Elizabeth as a motherly figure, Frankenstein's pursuit of recreating his dead mother's figurative representation in the form of his intellectual project, and Frankenstein's defiance of his father's gentle proscription of reading the outdated Agrippa, Paracelsus, and Albertus Magnus. Margaret Homans argues that the son desires a figurative representation of his mother in case he loses the physical body. By extending Homan's argument, Collings proposes that the novel prescribes and positions Elizabeth as a better substitute for Frankenstein than the monster.

Rose's film deviates from the textual trajectory by eliminating Caroline Beaufort and the Frankenstein family from the narrative. This altogether removes the possibility of projecting the Oedipal conflict onto Frankenstein's character. By highlighting the monster's persistent obsession for Elizabeth, Rose replaces one Oedipal complex with another within the narrative. Further, since Elizabeth is involved in the process of the monster's birth, the unidirectional growth of romance in her story with the monster increases the potency of social approbation of the incestuous affair since the motherly representative is not being contaminated.

Elizabeth's interest in participating in a romantic relationship with the monster could have instigated public boycott of the film because of the supposed corruption of 
the woman who is the embodiment of motherly virtues. The escalation of romantic affection within the monster places the narrative within the ambit of societal approval because while his affection appears romantic after the consideration of his deplorable plight, it is never reciprocated and his official union with a conscious Elizabeth is denied.

The monster's final encounter with Frankenstein and Elizabeth results in the assignment of a Biblical name to the monster when Elizabeth calls him 'Adam.' A semiotic analysis corroborated by theological validation and cultural acceptance suggests that the name is a reference to the Christian Adam who is considered the first man to have been made by the Christian God in his own image. Since the monster is the first kind of his species, he is supposed to bear semblance with Adam's character owing to the fact that both are the progenitors of their races. Even though the monster is primarily the product of Frankenstein's ambition, the insertion of Elizabeth's christening ceremony concretely establishes her as the maternal equivalent, thereby validating the evaluation of the Oedipal complex within the cinematic domain.

Finally, the episode where the monster carries Elizabeth in his arms and claims her unconscious body is aptly preceded by Elizabeth's assignment of the Biblical name, for it is not possible for him to extend his claim over her dying body in the complete absence of the nomenclative process. Before he is called 'Adam,' he is an abandoned creation. Afterward, not only does the monster receive maternal validation, but also the resolution of the narrative conflict, which is directed toward Elizabeth instead of Frankenstein in the film, is accomplished. Although the creation of the monster is primarily Frankenstein's ambition, the monster's early memories with Elizabeth and her eventual abandonment at the police station where she refuses to recognize him, shift the conflict and pilot it toward her. The conflation of the Oedipal complex and the orientation of Elizabeth as the monster's maternal guardian complicate the anatomy of the narrative purpose.

\section{CONCLUSION}

Maternal affection ultimately appears ambivalent when Elizabeth's feelings for the monster appear blurred in the film's narrative. The monster's appearance is sufficient to eradicate the possibility in which his phantasmagoria will be materialized into reality. This makes the possibility of his romantic, conjugal or sexual union with Elizabeth highly improbable.

\section{REFERENCES}

[1] O'Flinn, P. (1986). "Production and Reproduction: The Case of Frankenstein." Popular Fictions: Essays in Literature and History, London: Methuen: 194-213.

[2] Shelley, M. (2016). Frankenstein. Maya Joshi (Ed.). New Delhi: Worldview Publications.

[3] Rose, B. (2015). Frankenstein. Alchemy, 12 April 2015, https://www.netflix.com/in/, accessed 1 June 2020 on Netflix.

[4] Kant, I. (1987). Critique of Judgement. Werner Pluhar (trans.), Indianapolis: Hackett.

[5] Moers, E. (1976). Literary Women. Garden City: Doubleday.

[6] Gilles, D. (1986). Cinema 1: The Movement-Image. Hugh Tomlinson \& Barbara Haberjam (trans.). Minneapolis: University of Minnesota P.

[7] Shelley M.W., \& Smith, J.M. (2000). "Frankenstein: Complete, Authoritative Text With Biographical, Historical, And Cultural Contexts, Critical History, And Essays From Contemporary Critical Perspectives." Boston: Bedford/St. Martin's.

[8] Homans, M. (1986). Bearing the Word: Language and Female Experience in Nineteenth-Century Women's Writing. Chicago: University of Chicago Press. 